\title{
Correction to: Ecological Management: a Research Agenda
}

\section{Vincent Blok ${ }^{1}$}

Received: 8 June 2021 / Accepted: 8 June 2021/ Published online: 15 July 2021

(C) The Author(s), under exclusive licence to Springer Nature Switzerland AG. 2021

\section{Correction to: Philosophy of Management (2021) 20:1-4 https://doi.org/10.1007/s40926-021-00167-z}

The article Ecological Management: a Research Agenda, written by Vincent Blok, was originally published online on 12 February 2021 with Open Access under a Creative Commons Attribution (CC BY) licence 4.0. After publication in volume 20, issue 1, page 1-4 the author(s) decided to cancel the Open Access. Therefore, the copyright of the article has been changed on 4 June 2021 to (C) The Author(s), under exclusive licence to Springer Nature Switzerland AG 2021 with all rights reserved.

Publisher's Note Springer Nature remains neutral with regard to jurisdictional claims in published maps and institutional affiliations.

The online version of the original article can be found at https://doi.org/10.1007/s40926-021-00167-z

Vincent Blok

vincent.blok@wur.nl

1 Philosophy Group, Wageningen University (The Netherlands), Wageningen, Netherlands 